\title{
Cells per Liter
}

National Cancer Institute

\section{Source}

National Cancer Institute. Cells per Liter. NCI Thesaurus. Code C67241.

A unit of cell concentration expressed as a number of cells per unit volume equal to one liter. 